\title{
Screening of different maize (Zea mays L.) genotypes against salinity under hydroponics
}

\author{
Munaza Batool $^{1 *}$, Muhammad Saqib ${ }^{2}$, Muhammad Abdul Qayyum ${ }^{1}$, \\ Muhammad Jan ${ }^{1}$, Syeda Amber Hameed ${ }^{3}$, Ahmad Kamran Khan ${ }^{4}$, Athar \\ Khaliq ${ }^{1}$, Tayyaba Naz ${ }^{2}$, Arif Hussain ${ }^{1}$ and Shafqat Nawaz ${ }^{1}$ \\ 1. Department of Soil \& Environmental Sciences, Faculty of Agricultural Sciences, Ghazi University DG Khan \\ Punjab-Pakistan \\ 2. Institute of Soil \& Environmental Sciences, University of Agriculture Faisalabad Pakistan \\ 3. Department of Zoology faculty of Sciences, Ghazi University Dera Ghazi khan Punjab, Pakistan \\ 4. Department of Plant Protection, Faculty of Agricultural Sciences, Ghazi University DG Khan Punjab-Pakistan \\ *Corresponding author's email: munazabatool@gmail.com
}

Citation

Munaza Batool, Muhammad Saqib, Muhammad Abdul Qayyum, Muhammad Jan, Syeda Amber hameed, Ahmad Kamran Khan, Athar Khaliq, Tayyaba Naz, Arif Hussain and Shafqat Nawaz. Screening of different maize (Zea Mays L.) genotypes against salinity under Hydroponics. Pure and Applied Biology. Vol. 9, Issue 1, pp1118-1129. http://dx.doi.org/10.19045/bspab.2020.90117

\begin{tabular}{llll}
\hline \hline Received: 03/10/2019 & Revised: 31/12/2019 & Accepted: 07/01/2020 & Online First: 30/01/2020 \\
\hline
\end{tabular}

\section{Abstract}

Growth and development of a crop or even cultivars within a species of a crop respond to soil salinity since germination. Twenty the most growing varieties of maize (Zea mays L.) genotypes were used in this study. The sterilized and healthy seeds of twenty maize genotypes were sown in trays containing two inches' layers of gravel. The experiment comprised two levels i.e $100 \mathrm{mM}$ $\mathrm{NaCl}$ was developed step wise with $\mathrm{NaCl}$ salt, whereas no salt was added in control for hydroponic experiment, designed in two factorials Complete Randomized Design (CRD) with three replications on four cultivars with the design of experiment was completely randomized with five replicates and factorial arrangement. Results showed that the highest shoot fresh and dry matter was produced by EV-5098 whereas the minimum shoot fresh and dry weight was produced by Pak-afgooe due to higher accumulation of $\mathrm{Na}^{+}$in its leaves and lower concentration of $\mathrm{K}^{+}$and $\mathrm{K}^{+}$: $\mathrm{Na}^{+}$ratio which depreciated its performance. There is a significant increase in $\mathrm{Na}^{+}$concentration while concentration of $\mathrm{K}^{+}$and $\mathrm{K}^{+}: \mathrm{Na}^{+}$ratio is significantly decreased under saline conditions. Results indicated that root and shoot length, number of leaves plant-1, fresh and dry mass production varied with $\mathrm{NaCl}$ stress which indicating that some cultivars of maize seedlings are highly susceptible to concentrated $\mathrm{NaCl}$.

Keywords: Hydroponic; Maize; $\mathrm{NaCl}$ stress; Root length; Sensitivity and shoot length

\section{Introduction}

After wheat and rice, maize (Zea mays L.) is the third most important cereal crop in Pakistan, Salt-affected area in the world, is
1128 million hectare (Mha) [1], 226 Mha of land are irrigated [2]. Farmers grow maize (Zea mays L.) as an essential food grain in all climates from warm to tropical prevailed in 
various parts of the world. World maize production was approx. 1067 million tons, in 2016 [3].The stressful abiotic conditions such as water and salinity stresses and cold temperature, reduces its performance in terms of production, while the crop meets up human diet with the nutritional quality of the grain [4]. Therefore, study on the efficient technique can be developed for the purpose tolerance of maize cultivars to salinity through evaluation and selection of maize cultivars is a great necessity [5]. Salinity effect the crop is flexible at altered growth stages [6]. For resistance to salinity and drought at the seedling stage a very high genotypic variability in maize cultivars exists. For resistance to drought and salinity stresses diverse genotypes of the crop have also been selected [7]. At the germination stage maize crop transported high amount of $\mathrm{Na}+$ and $\mathrm{Cl}$ - to the growing part of shoot and in course of time, $\mathrm{Ca} 2+$ and $\mathrm{K}+$ concentrations decreased in the tissues located in embryonic part [8]. Osmotic ion and oxidative stress are the effect of salinity on plant growth. Glycophytes and halophytes got adjusted osmotically with the increase in accumulated solutes in inorganic and organic forms [9] which finally causes larger decrease in cell solute potential than external salinity. This may be recognized to balancing the accumulated organic solutes in the cytosol with the solute potential of the ionsdominated-vacuoles [10]. A progressive correlation between the adaptation to stress and osmolyte accumulation has been well documented. By different authors

molecular mechanism of salt tolerance has been well accepted [11]. Therefore, present study was conducted to Screen out the different maize (Zea Mays L.) genotypes against salinity under Hydroponics conditions.

\section{Materials and methods}

\section{Growing site}

This research experiment was started in the airport campus of the Ghazi University Dera Ghazi Khan Punjab, Pakistan. The climate condition of the study area was hot summer $\left(25-50{ }^{0} \mathrm{C}\right)$ and cold winter $\left(0-21{ }^{0} \mathrm{C}\right)$ with very low rainfall rate. Twenty varieties were selected on the basis of most cultivated varieties in our project area (Table 1).

Table 1. List of tested genotypes

\begin{tabular}{|c|c|c|c|}
\hline Sr. No. 1 & Tested varieties & Sr. No. 1 & Tested varieties \\
\hline 1 & Sahiwal 2002 & 11 & $32-$ B-33 \\
\hline 2 & Monsento6142 & 12 & 8711 \\
\hline 3 & 8441 & 13 & Ev-5098 \\
\hline 4 & FH-985 & 14 & Etc \\
\hline 5 & Monsento6542 & 15 & FH-793 \\
\hline 6 & EV-78 & 16 & FH-782 \\
\hline 7 & Sadaf & 17 & EV-77 \\
\hline 8 & EV-1098 & 18 & $32-\mathrm{M}-15$ \\
\hline 9 & $32-T-16$ & 19 & 6525 \\
\hline 10 & Pak-Afgoee & 20 & 6143 \\
\hline
\end{tabular}




\section{Growing condition}

In this study twenty genotypes of maize (Zea mays L.) were used. The healthy and sterilized seeds was sown in trays containing two inches' layers of gravel. After transplanting salinity level which was required i.e. $100 \mathrm{~m} \mathrm{M} \mathrm{NaCl}$ was developed step wise with $\mathrm{NaCl}$ salt, whereas in control no salt was added. The $\mathrm{pH}$ of solution was maintained between 5.5 and 6.5 with dilute solution of $\mathrm{HCl}$ and/or $\mathrm{NaOH}$ solution.

\section{Data collection}

After four weeks of transplanting plants were harvested and the data regarding

1-root/ shoot lengths,

2-root/shoot fresh and dry weights,

3 -and ion contents $\left(\mathrm{Na}^{+}\right.$and $\left.\mathrm{K}^{+}\right)$of the dry plant material was determined.

\section{Analysis}

The data were collected was analyzed using an appropriate statistical package. The design of experiment was completely randomized with five replicates and factorial arrangement.

\section{Results}

\section{Shoot and root growth}

Salt stress resulted in a significant weakening in shoot fresh and dry weights of all the maize genotypes (Fig. $1 \& 2$ ). The difference between treatments, genotypes and their interaction was significant for mutually these parameters. In the saline treatment they differed significantly from one and other however in the control treatment, genotypes did not differ significantly however in. Like root growth salinity caused the corresponding decline in the shoot growth as well (Fig. $3 \& 4$ ). For both root fresh and dry weights the main effects as well as their interaction were significant. Shoot and root length was also decreased due to salinity stress (Fig. $5 \& 6$ ). Although genotypes did not differ significantly from each other, however the treatments have significant effect for shoot. $E v-5098$ produced more soot and root length at $100 \mathrm{mM} \mathrm{NaCl}$ level as related to other genotypes and it was also statistically significant from all others. The salt stress and genotypes have significant effect on relative shoot fresh weight (Fig. 7). Pak-afgoee showed the minimum relative shoot fresh weight while the maximum relative shoot fresh weight was observed in Ev-5098 that was $42 \%$.

\section{Leaf ionic composition}

Leaf $\mathrm{Na}^{+}$concentration increased significantly in all the genotypes due to Salinity (Fig. 8). The interactive as well as individual effects of genotypes and treatment were found significant. The comparison of all the genotypes under salinity treatment $(100 \mathrm{mM} \mathrm{NaCl})$ indicated that $E v-5098$ and $E v-78$ stored significantly lower $\mathrm{Na}^{+}$as compared to other genotypes. In this treatment, the maximum $\mathrm{Na}^{+}$concentration $\left(0.7 \mathrm{mmol} \mathrm{g}^{-1} \mathrm{dwt}\right)$ was found in the leaves of Pak-afgoee. At the same salinity level leaf $\mathrm{Na}^{+}$concentration was $0.68 \mathrm{mmol} \mathrm{g}{ }^{-1} \mathrm{dw}$ in Monsento-6525. The concentration of $\mathrm{K}^{+}$as against of $\mathrm{Na}^{+}$decreased significantly at $100 \mathrm{mM} \mathrm{NaCl}$ salinization (Fig. 9). The individual effects of treatments and genotypes as well as their interaction were found significant. In control treatment $\mathrm{K}^{+}$ concentration was the higher than $100 \mathrm{mM}$ $\mathrm{NaCl}$. The comparison of genotypes at control and salinity level showed that $E v$ 5098 accumulated more $\mathrm{K}^{+}$in leaf as compared to other genotypes. At $100 \mathrm{mM}$ $\mathrm{NaCl}$, leaf $\mathrm{K}^{+}$concentration was $0.38 \mathrm{mmol}$ $\mathrm{g}^{-1} \mathrm{dwt}$ in Ev-5098 where as in case of Pakafgoee it was $0.25 \mathrm{mmol} \mathrm{g}^{-1} \mathrm{dwt}$. The $\mathrm{K}^{+}: \mathrm{Na}^{+}$ ratio was the higher in control treatment than in $100 \mathrm{mM} \mathrm{NaCl}$ treatment. FH-985 had higher $\mathrm{K}^{+}: \mathrm{Na}^{+}$ratio than all other genotypes under control treatments while Ev-5098 had higher $\mathrm{K}^{+}: \mathrm{Na}^{+}$ratio than all other genotypes under saline conditions (Fig. 10). 


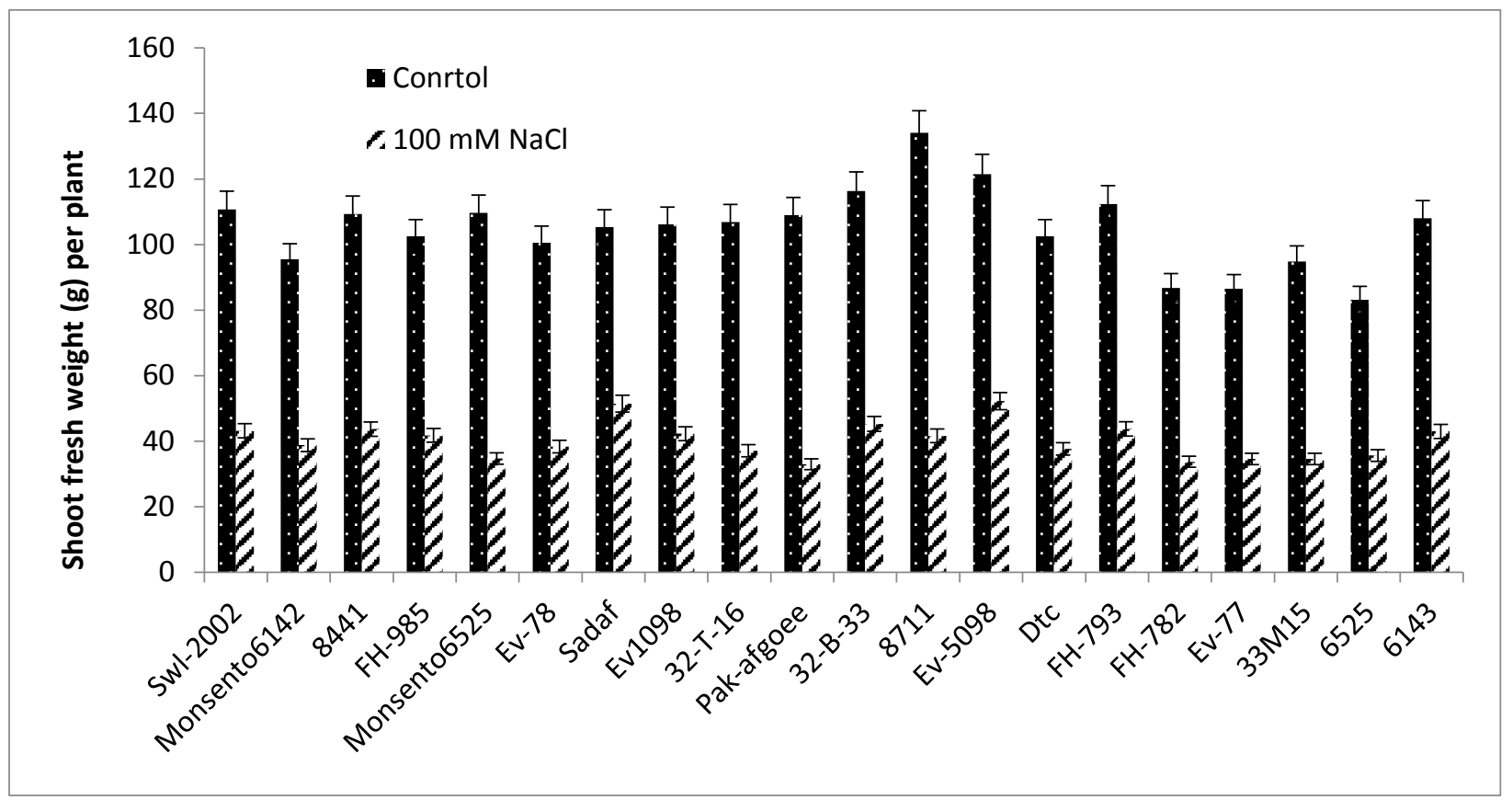

Figure 1. Shoot fresh weight of different maize genotypes against $\mathrm{NaCl}$ salt stress

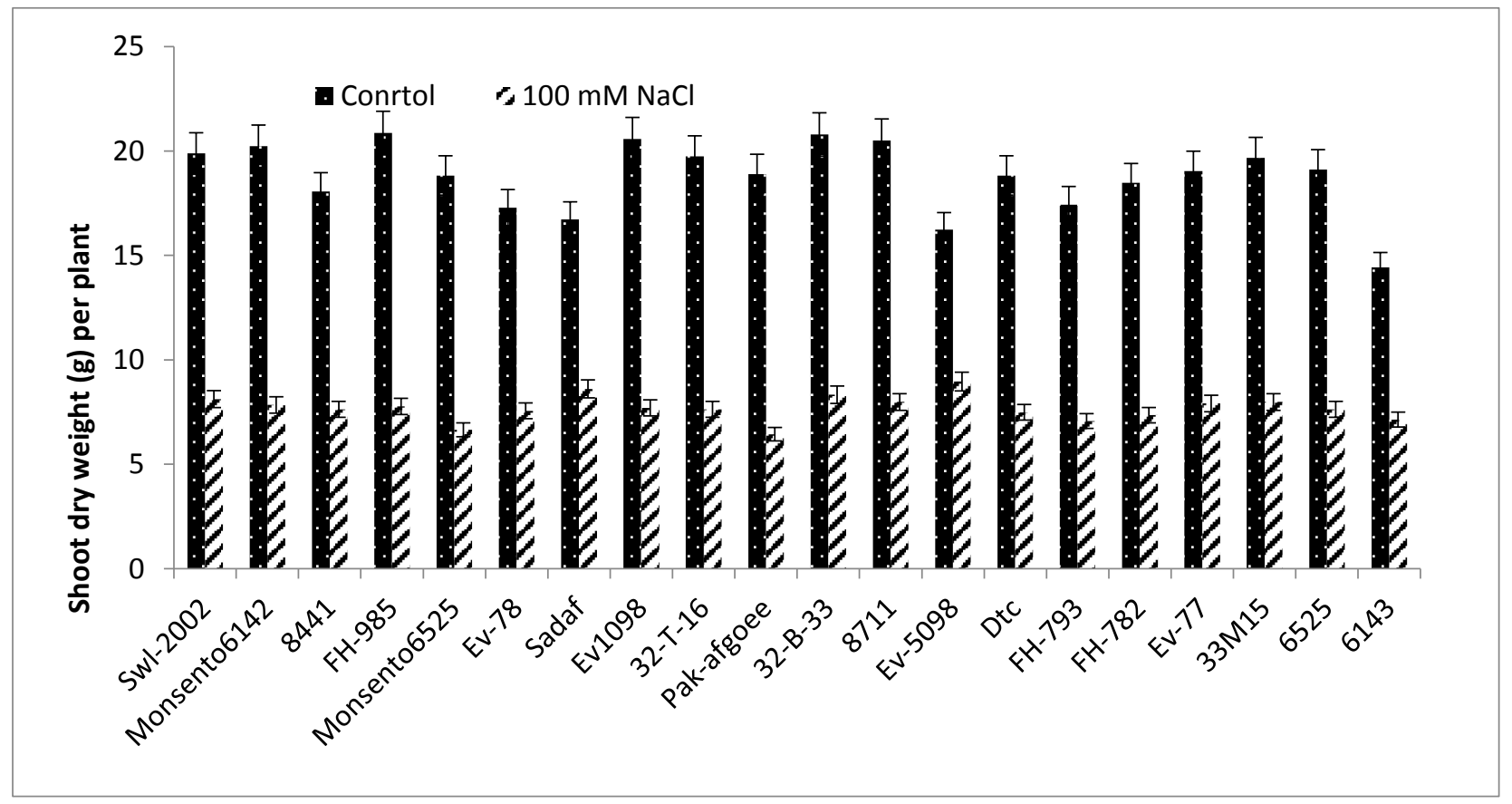

Figure 2. Shoot dry weight of different maize genotypes against $\mathrm{NaCl}$ salt stress 


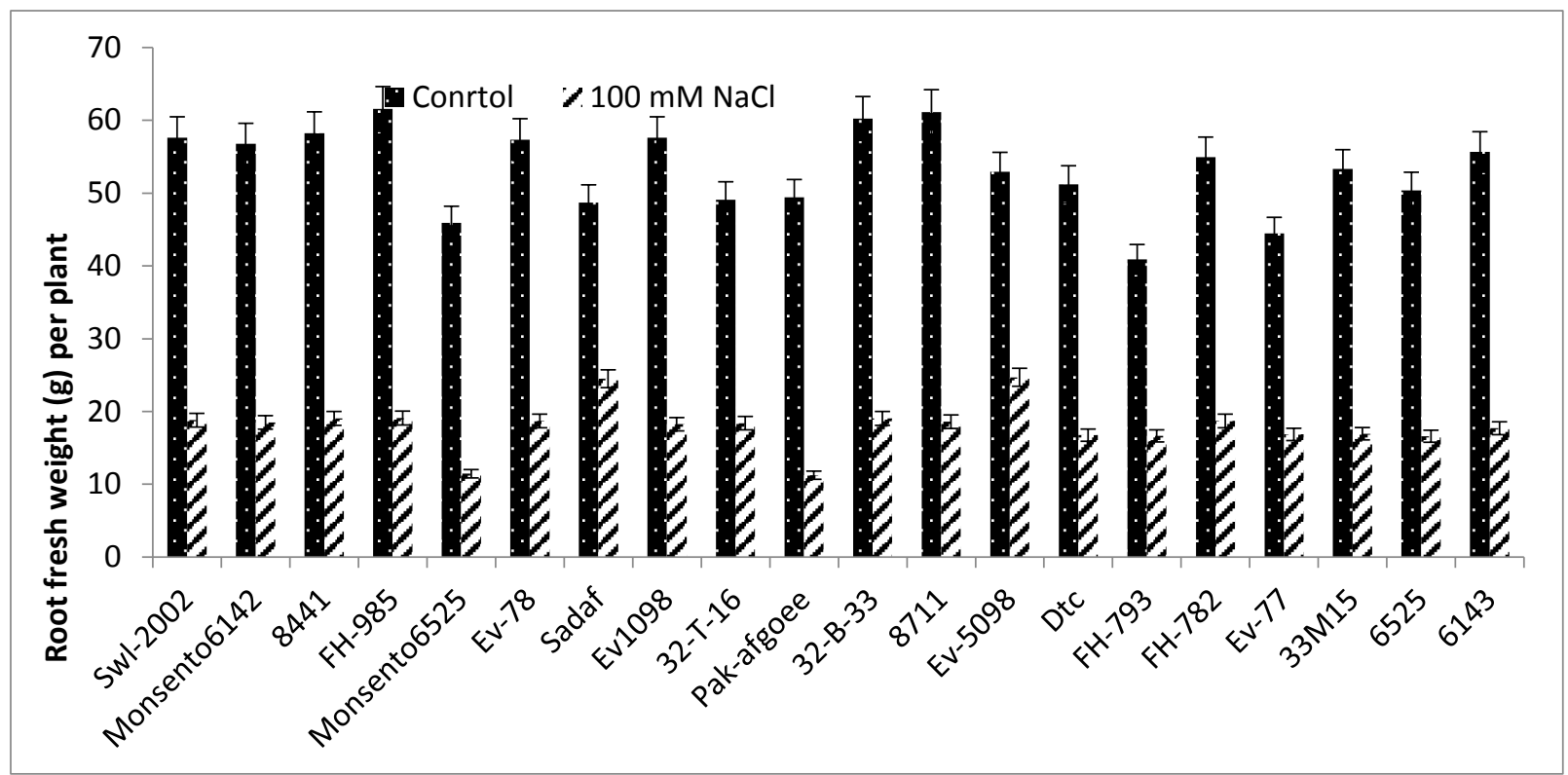

Figure 3. Root fresh weight of different maize genotypes against $\mathrm{NaCl}$ salt stress

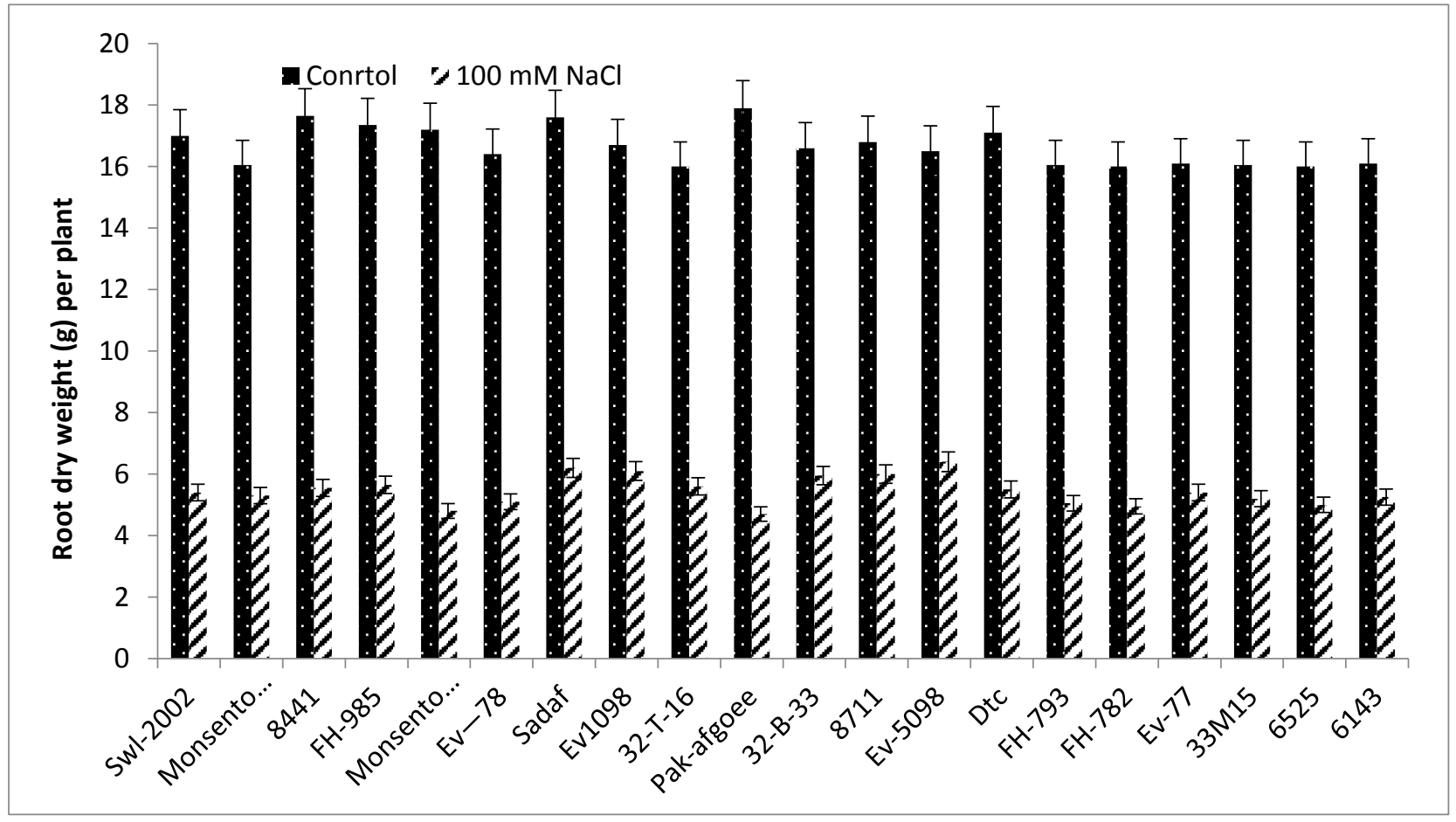

Figure 4. Root dry weight of different maize genotypes against $\mathrm{NaCl}$ salt stress 


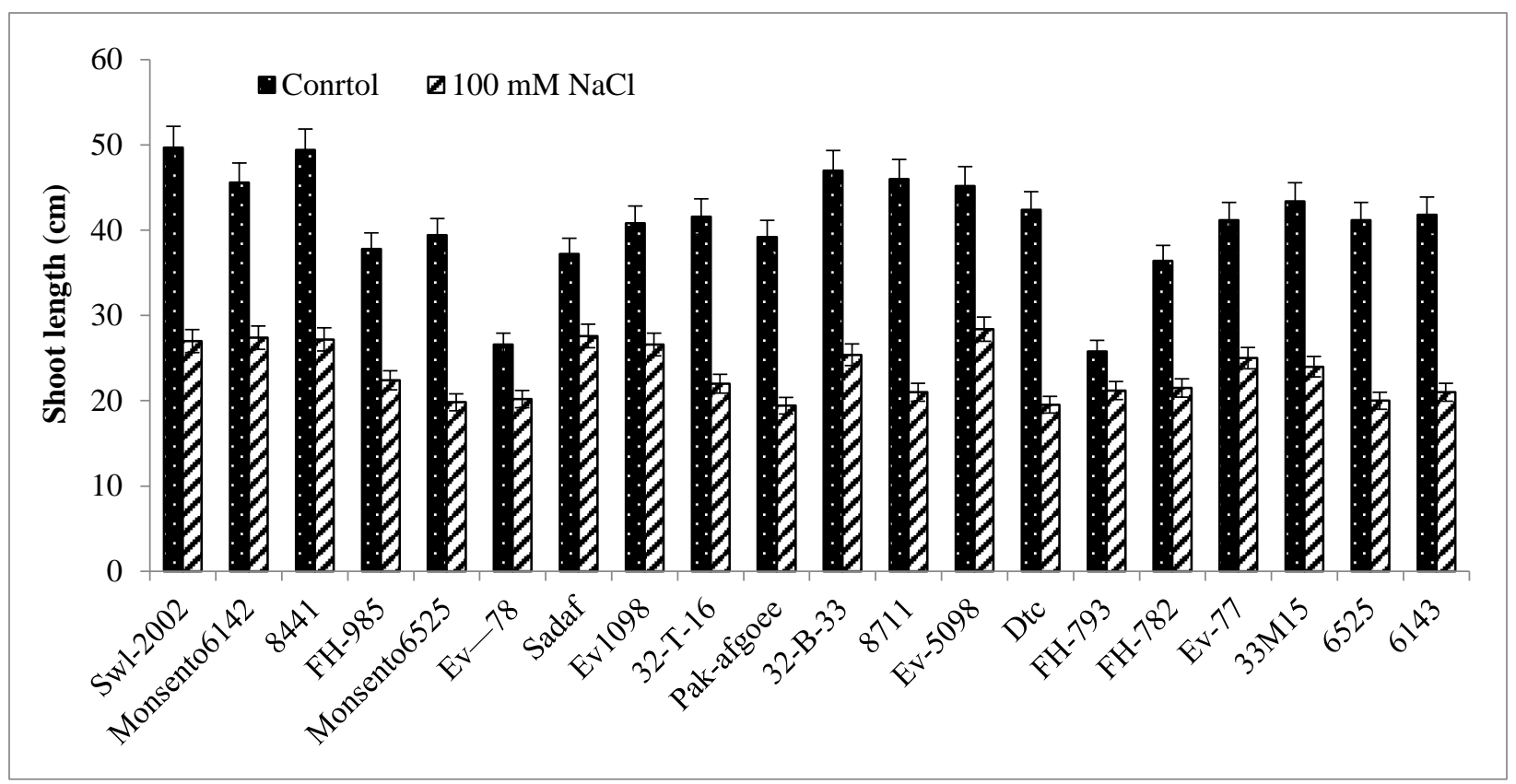

Figure 5. Shoot length of different maize genotypes against $\mathrm{NaCl}$ salt stress

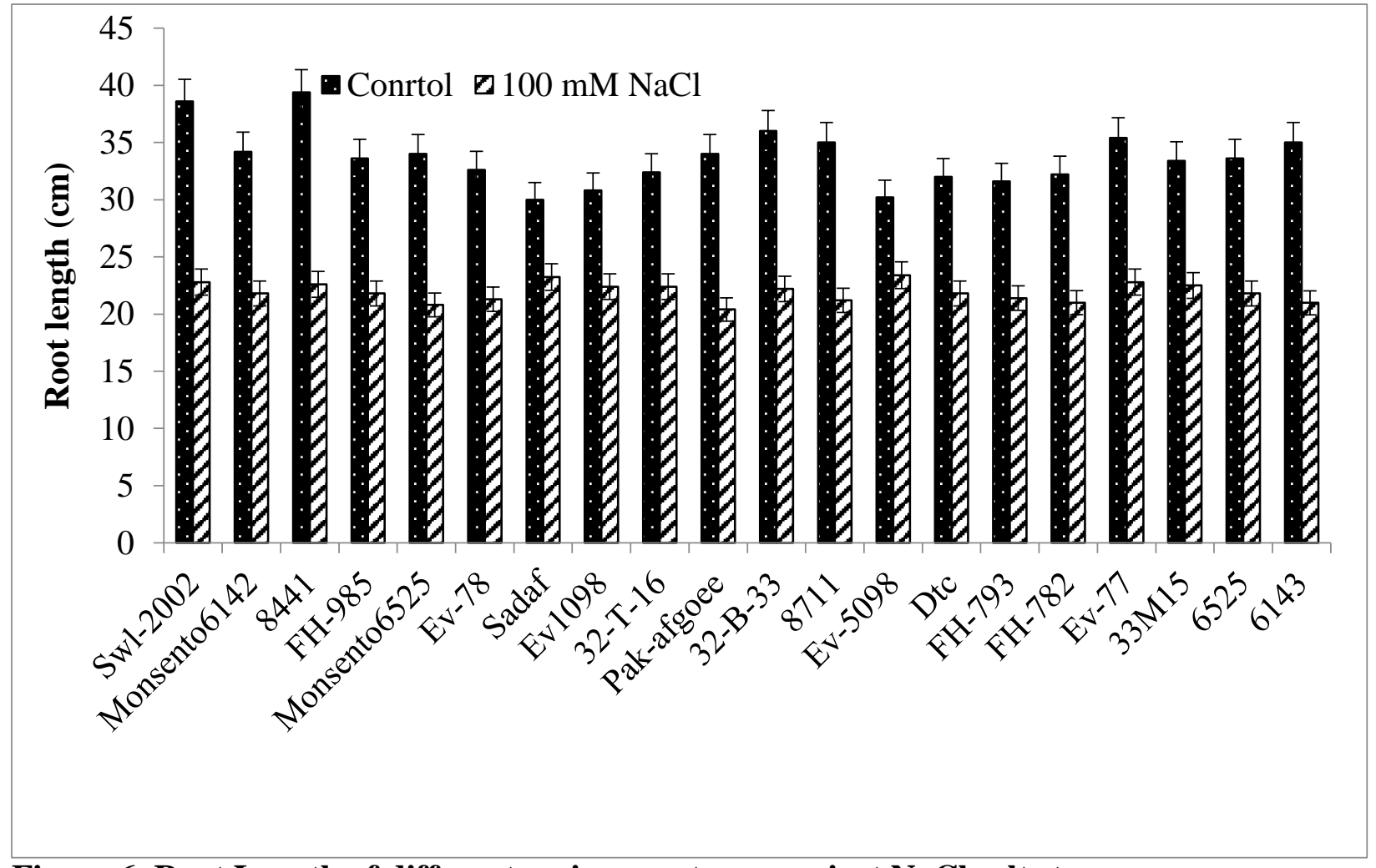

Figure 6. Root Length of different maize genotypes against $\mathrm{NaCl}$ salt stress 


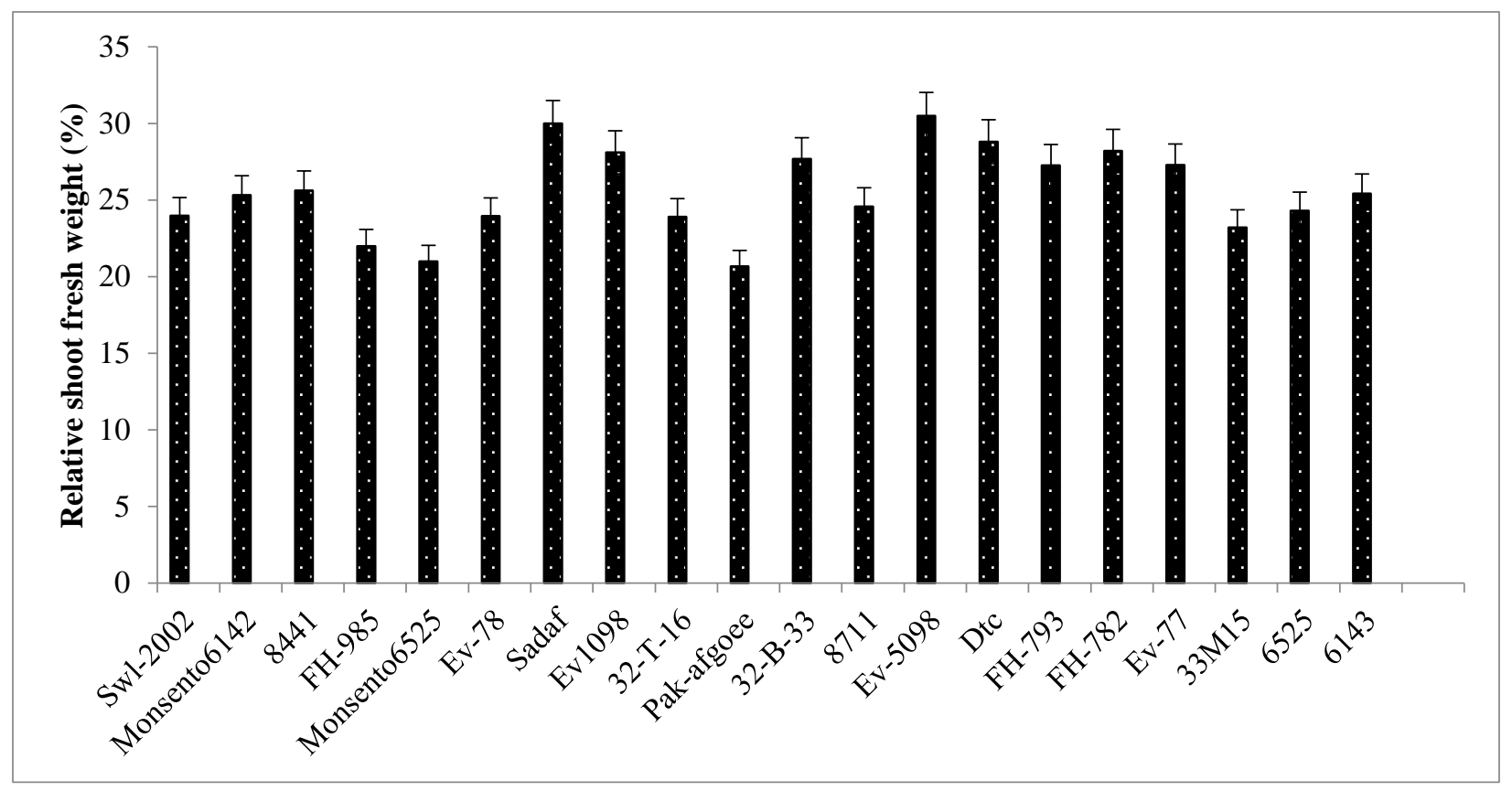

Figure 7. Relative shoot fresh weight of different maize genotypes against NaCl salt stress

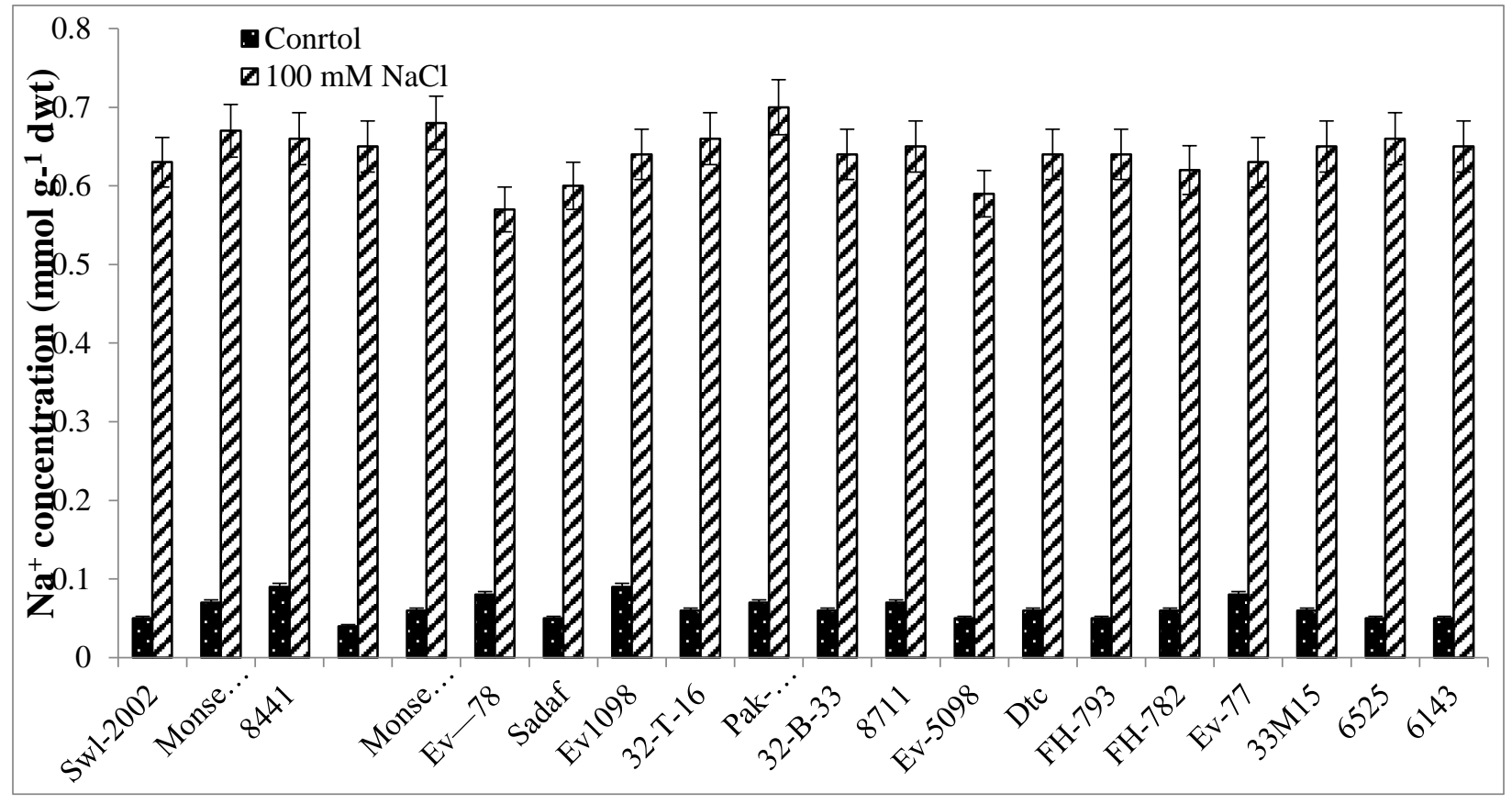

Figure 8. Shoot Sodium concentration of different maize genotypes against $\mathrm{NaCl}$ salt stress 


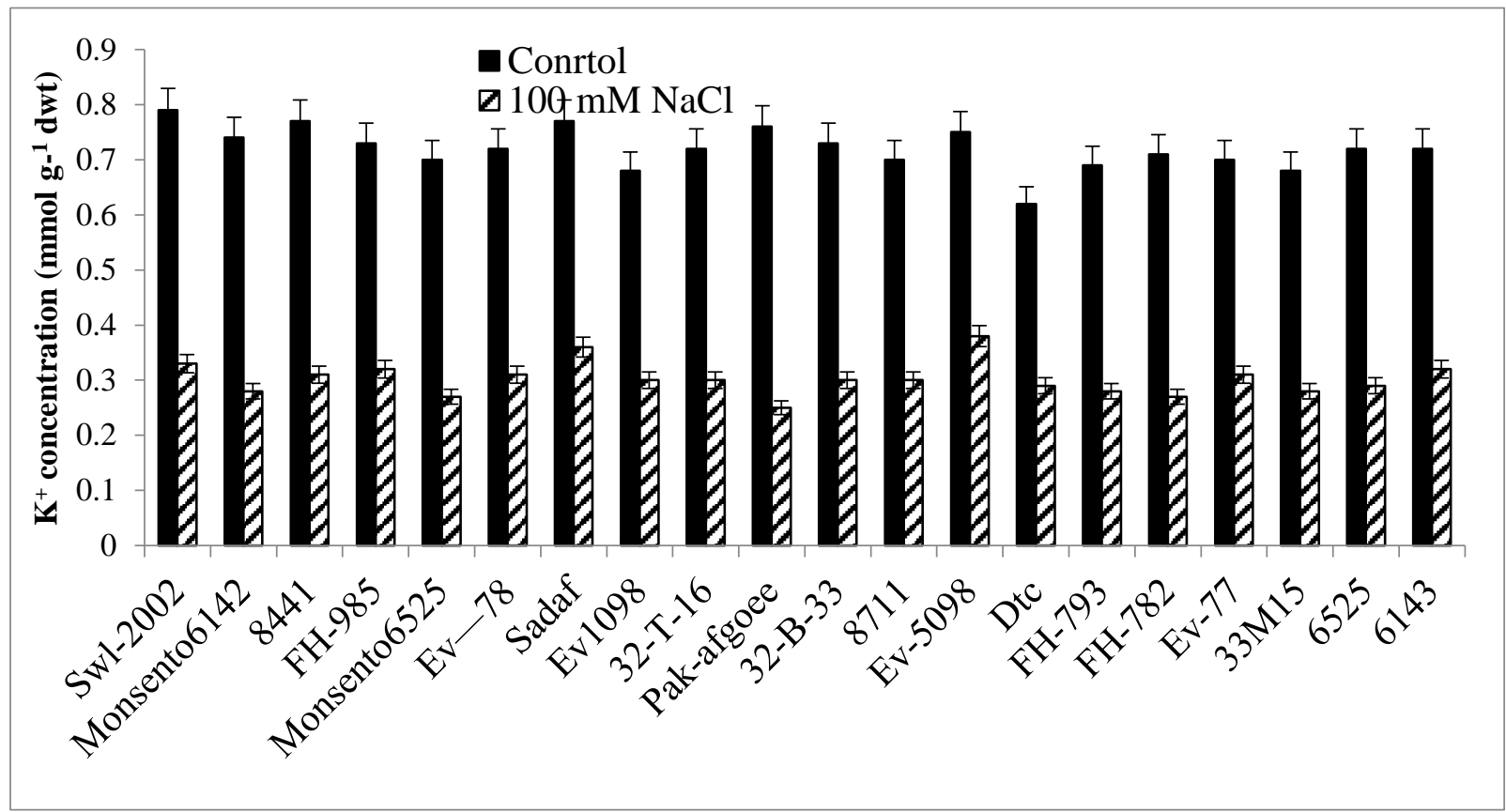

Figure 9. Shoot potassium concentration of different maize genotypes against $\mathrm{NaCl}$ salt stress

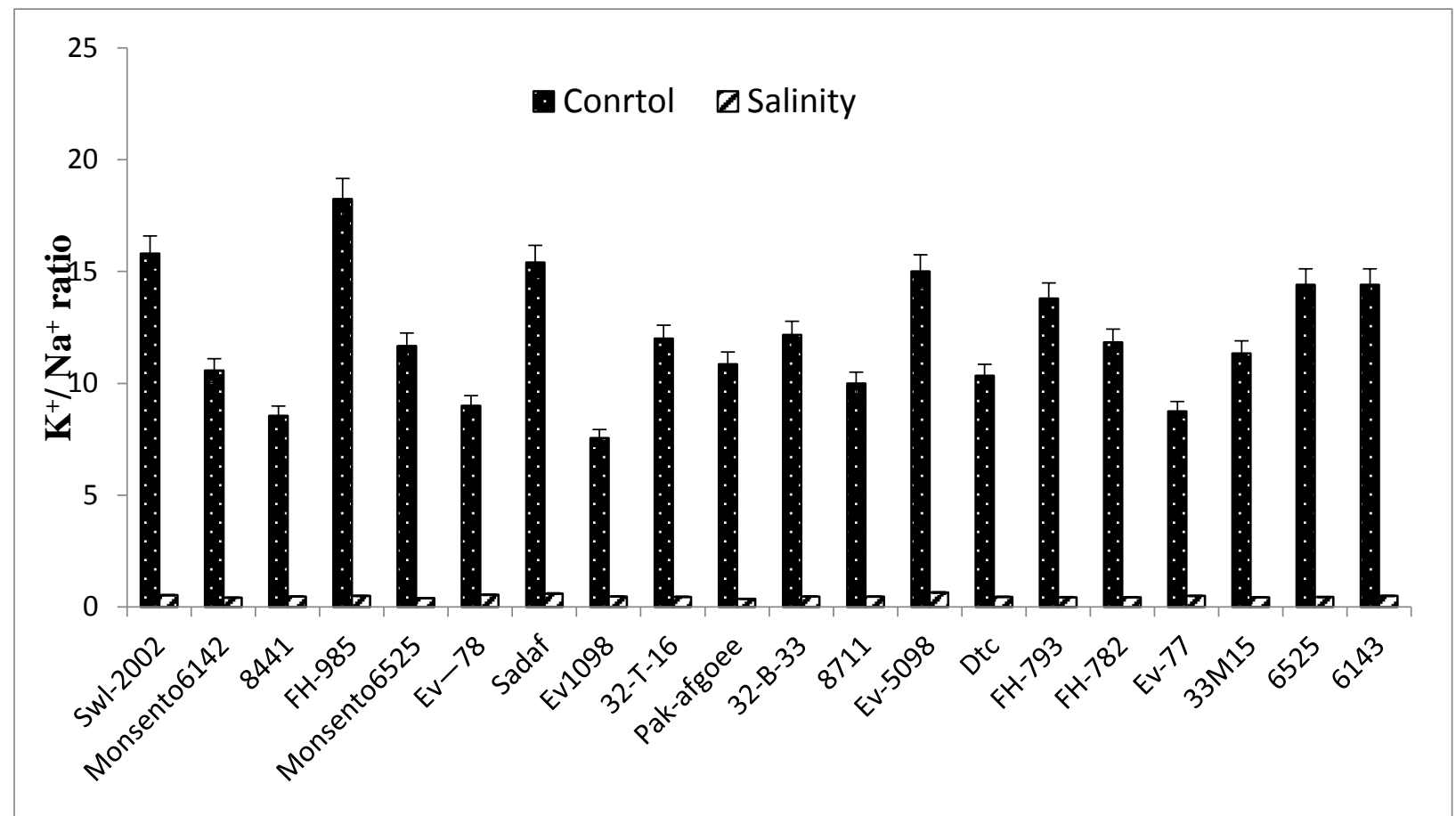

Figure 10. Shoot potassium to sodium ratio of different maize genotypes against $\mathrm{NaCl}$ salt stress 


\section{Discussion}

This hydroponic study was directed to evaluate different maize genotypes for leaf ionic composition and their growth performance in response to salinity. This study shows that salt stress has a negative effect on the growth of all the genotypes of maize as there was a significant reduction in their growth parameters under salt stress (100 $\mathrm{mM} \mathrm{NaCl}$ ). According to [12] salinity is a primary environmental factor decreasing plant growth and yield. Decline in plant growth as a result of salinity condition has been reported in many species [13-15]. High salinity concentration interrupts several physiological processes of plants, which effects in reduction in plant growth and development [16]. Salinity decreases water potential in the maize leaves, plant height and stem dry mass [17]. It also affects xylem water transport, leaf elongation, root length and root hydraulic conductivity of maize [18, 19]. According to [20] salt stress significantly reduces the leaf area of maize, shoot length, fresh and dry weight of shoots with increasing intensity of salt stress.

The results of the present study indicated that under salinity concentration of $\mathrm{K}^{+}$and $\mathrm{K}^{+}$. $\mathrm{Na}^{+}$ratio is significantly decreased while there is a significant increase in $\mathrm{Na}^{+}$ concentration. Under salinity accumulation of the toxic ions $\left(\mathrm{Na}^{+}\right)$has been also observed earlier [21, 22]. In plants the main reason of growth reduction under salinity is the the presence of toxic $\mathrm{Na}^{+}$and $\mathrm{Cl}^{-}$[23]. [24] showed that there is a negative relationship among the biomass of aerial organs and $\mathrm{Na}^{+}$ content. So, in this study similar relationship has also been found (Fig. 11). [25] stated that salt tolerant maize genotypes have low shoot $\mathrm{Na}^{+}$concentration which shows that exclusion of $\mathrm{Na}^{+}$is positively related to salt tolerance in maize. Under salinity a high
$\mathrm{Na}^{+} / \mathrm{K}^{+}$ratio in the tissues, disturbance of $\mathrm{K}^{+}$ nutrition results in salt injury in many plants [25-28]. High concentration of potassium in leaf enables osmotic regulation with relatively less energy expenditure than the accumulation of compatible solutes $[29,30]$. For more than 50 plant enzymes the $\mathrm{K}^{+}$is essential as a co-factor and these enzymes are mostly affected by high $\mathrm{Na}^{+}$and low $\mathrm{K}^{+} / \mathrm{Na}^{+}$ ratios [31].

Within saline treatment, genotypic variation has also been observed, the minimum shoot fresh and dry weight was produced by Pakafgooe whereas the highest shoot fresh and dry matter was produced by EV-5098 due to higher accumulation of $\mathrm{Na}^{+}$in its leaves and lower concentration of $\mathrm{K}^{+}$and $\mathrm{K}^{+}: \mathrm{Na}^{+}$ratio which deteriorated its performance. Different genotypes also showed different relationship between growth and leaf ionic composition. Plant species and their genotypes differ greatly in growing under salt stress conditions [32, 33]. Maize is a major cereal crops and is relatively sensitive to salinity $[34,35]$ and this sensitivity depends upon the genotype [36]. Halperin et al. [36] reported $40 \%$ decline in dry weight of maize genotype when exposed to $100 \mathrm{mM} \mathrm{NaCl}$ salinity. According to [37], the maize genotype Zea mays L. proved to be more resistant than the Pioneer-3578. Maize genotypes G2 and SRO73 have been observed as more salt tolerant maize cultivars than the other in a long-term experiment [38, 39]. Saline environment results in a greater increase in cytoplasmic $\mathrm{Na}^{+}$content in the salt sensitive variety than in the resistant variety [40]. According to Hollington [41] salt resistant variety contains low $\mathrm{Na}^{+}$and high $\mathrm{K}^{+}$content as compared to salt sensitive variety. On the basis of these results Ev-5098 has been selected as salt tolerant and Pak-afgoee as salt sensitive maize genotypes. 


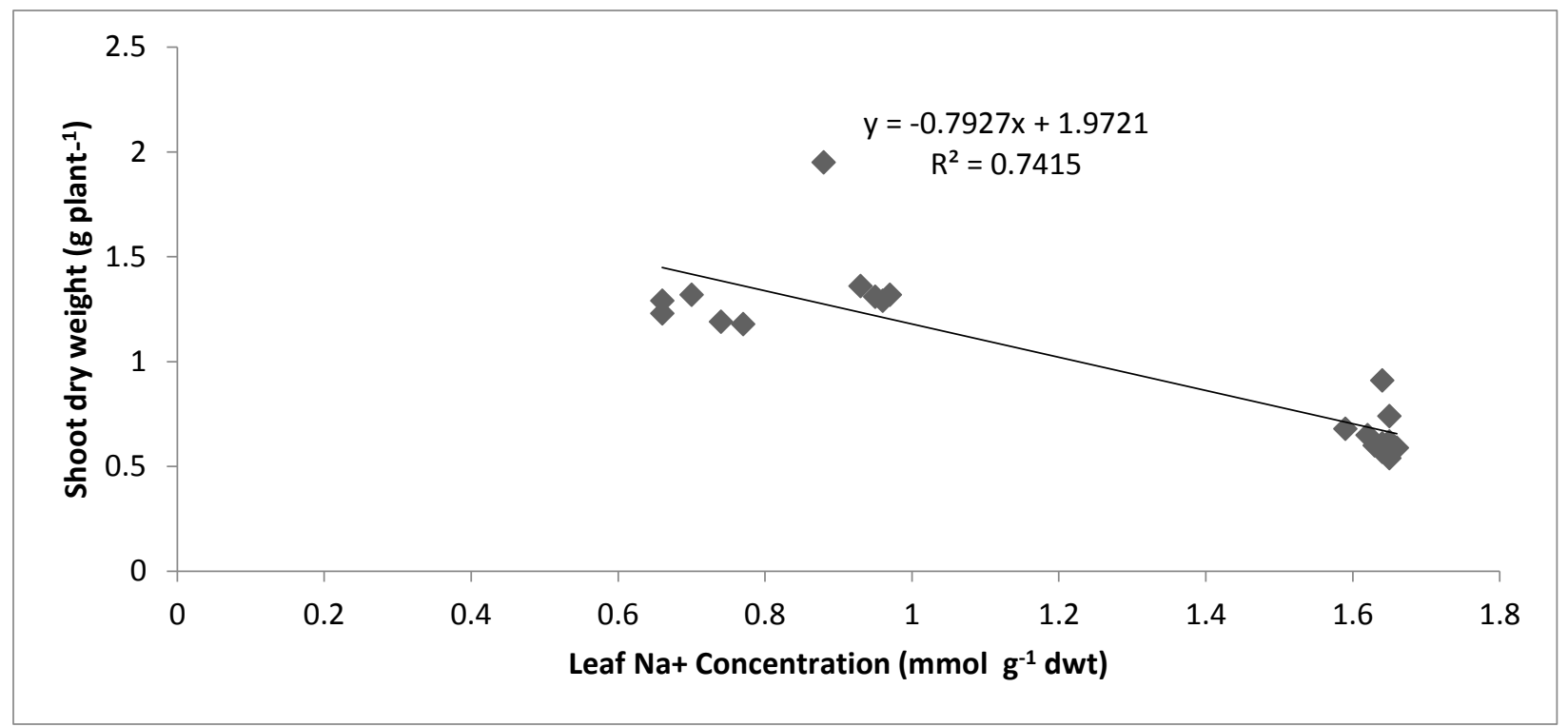

Figure 11. Relationship between leaf $\mathrm{Na}^{+}$and shoot dry weight $\left(\mathrm{g} \mathrm{plant}^{-1}\right)$ of different maize genotypes

\section{Conclusion}

Twenty maize genotypes were evaluated in Hoagland's nutrient solution under treatments i.e. control and $100 \mathrm{mM} \mathrm{NaCl}$. Regarding results of growth and ionic relations, significant differences were recorded among the maize genotypes. Results of this study revealed that salt tolerant genotypes (EV-5098) produced more shoot fresh and dry weights, had less accumulation of $\mathrm{Na}^{+}$and showed higher $\mathrm{K}^{+}: \mathrm{Na}^{+}$ratio, whereas less shoot fresh and dry weights and high accumulation of $\mathrm{Na}^{+}$ and lower $\mathrm{K}^{+}: \mathrm{Na}^{+}$ratio was noted in the salt sensitive (Pak-afgoee).

\section{Authors' contributions}

Conceived and designed the experiments: $\mathrm{M}$ Batool, M Saqib \& S Nawaz, Performed the experiments: M Batool, Analyzed the data: A Khaliq, T Naz \& A Hussain, Contributed materials/ analysis/ tools: MA Qayyum \& M Jan, Wrote the paper: M Batool, SA Hameed \& AK Khan.

\section{References}

1. Abari AK, Nasr MH, Hojjati M \& Bayat D (2011). Salt effects on seed germination and seedling emergence of two Acacia species. Afr J Plant Sci 5: 5256.

2. Abdall FE, Zeinab MM \& El-Sayed A.A (1992). Effect of micronutrients foliar application on uptake of macronutrients by wheat and faba bean. Afr J Agric Sci 19(1): 181-192.

3. Abd-El Baki GK, Siefritz, Man HM, Weiner H, Kaldenhoff R \& Kaiser WM (2000). Nitrate reductase in Zea mays L. under salinity. Plant Cell Environ 25: 5151-521.

4. Abrol IP, Yadov JSP \& Massiud FI (1988). Salt affected soils and their management. J Plant Nutr 18: 14031408.

5. Ahmad K, Saqib M, Akhtar J \& Ahmad R (2012). Evaluation and characterization of genetic variation in maize (Zea mays L.) for salinity tolerance. Pak J Agric Sci 49: 521-526.

6. Ahmad S, Wahid A, Rasul E \& Wahid A (2005). Comparative morphological and physiological responses of green gram genotypes to salinity applied at different growth stages. Bot Bull Acad Sin 46: 135-142. 
7. Akbar M \& Yabuno T (1977). Breeding saline-resistant varieties of rice. IV. Inheritance of delayed type panicle sterility induced by salinity. Jpn J Breed 27: 237-240.

8. Akram M, Ashraf M, Ahmad Y, Waraich R, Iqbal J \& Mohsen M (2010). Screening for salt tolerance in maize (Zea mays L.) hybrids at an early seedling stage. Pak J Bot 42(1): 141-154.

9. Badawi GH, Yamauchi Y, Shimada E, Sasaki R, Kawano N \& Tanaka K (2004). Enhanced tolerance to salt stress and water deficit by overexpressing superoxide dismutase in tobacco (Nicotiana tabacum) chloroplasts. Plant Sci 166: 919-928.

10. Badia D \& Meiri A (1994). Tolerance of two tomato cultivars (Lycopersicum esculentum Mill) to soil salinity during emergence phase. Agr Med 124: 301310.

11. Bar-Tal A, Feigenbaum S \& Sparks DL (2004). Potassium-salinity interactions in irrigated corn. Irrig Sci 12: 27-35.

12. Bayuelo-Jimenez JS, Craig R \& Lynch JP (2002). Salinity tolerance of Phaseolus species during germination and early seedling growth. Crop Sci 42: 1584-1594.

13. Benes SE, Aragues R, Grattan SR \& Aystin RB (1996). Foliar and root absorption of $\mathrm{Na}^{+}$and $\mathrm{Cl}^{-}$in maize and barley: Implications for salt tolerance screening and the use of saline sprinkler irrigation. Plant Soil 180: 75-80.

14. Bernstein N, Silk WK \& Läuchli A (1995). Growth and development of sorghum leaves under conditions of $\mathrm{NaCl}$ stress: possible role of some mineral elements in growth inhibition. Planta 196: 699-705.

15. Bethke PC \& Drew MC (1992). Stomatal and non-stomatal components to inhibition of photosynthesis in leaves of
Capsicum annuum during progressive exposure to $\mathrm{NaCl}$ salinity. Plant Physiol. 99: 219-226.

16. Bhutta ZA, Jiwani A, Feroze A Kissana N \& Ortiz-Monasterio I (2007). Assessment of Human Zinc Deficiency and Determinants in Pakistan: Implications for Interventions. Improving Crop Production and Human Health, May 24-25. Istanbul, Turkey.

17. Blanco MJ, Morales MA, Torrecillas A \& Alarcon JJ (1998). Diurnal and seasonal osmotic potential changes in Lotus creticus plants grown under saline stress. 136: 1-10.

18. Blumwald E (1987). Tonoplast vesicles for the study of ion transport in plant vacuoles. Physiol Plant 69: 731-734.

19. Bohnert HJ, Nelson DE \& Jensen RG (1995). Adaptations to environmental stresses. Plant Cell 7: 1099-1111.

20. Cramer GR, Epstein E \& Läuchli A (1988). Kinetics of root elongation of maize in response to short-term exposure to $\mathrm{NaCl}$ and elevated calcium concentration. J Exp Bot 39: 1513-1522.

21. Crosbie TM \& Pearce RB (1982). Effects of recurrent phenotypic selection for high and low photosynthesis on agronomic traits in two maize populations. 22: 809-813.

22. Datnoff LE, Snyder GH \& Korndorfer GH (2001). Silicon in Agriculture. Elsevier Sci, The Netherlands.

23. Debjit B, Chiranjib KP \& Sampath K (2010). A potential medicinal importance of zinc in human health and chronic disease Int J Pharm Biomed Sci 1(1): 05-11.

24. Dubey RS (2005). Photosynthesis in plants under stressful conditions. In: Pessarakli, M. (Ed.), Handbook of Photosynthesis, Second ed. CRC Press, New York. pp 717-718.

25. Dvorak J, Noaman MM, Goyal S \& Gorham J (1994). Enhancement of the 
salt tolerance of Triticumn turgidumn $\mathrm{L}$. by the Knzal locus transferred from the Triticumn aestivumn L. chromosome 4D by homoeologous recombination. Theor Appl Gen 87: 872-877.

26. El-Fouly MM, Mobarak ZM \& Salama ZA (2010). Improving tolerance of faba bean during early growth stages to salinity through micronutrients foliar spray. Not Sci Biol (2): 98-102.

27. Flowers TJ (2004). Recent advances in genetics of salt tolerance in tomato. Plant Cell Tissue Organ Cult 76: 28-39.

28. Flowers TJ \& Yeo A (1995). Breeding of salinity resistance in crop plants. Aust. $J$. Plant Physiol 22: 875-884.

29. Foolad MR (2004). Recent advances in genetics of salt tolerance in tomato. Plant Cell Tissue Organ Cult 76: 101119.

30. Fortmeier R \& Schubert S (1995). Salt tolerance of maize (Zea mays L.): The role of sodium exclusions. Plant Cell Environ. 18: 1041-1047.

31. Garg BK \& Gupta IC (1997). Saline wastelands environment and plant growth, Jodhpur, India, Sci Publ 287.

32. Garg BK \& Gupta IC (1997). Saline Wastelands Environment and Plant Growth, Jodhpur, India. Sci Publ 287: 33-38.

33. Gelarch H, Ben-Shachar D, Reiderer P \& Youdim MB (1994). Altered brain metabolism of iron as a causes of neurodegenerative diseases. $J$ Neurochem 63: 793-807.

34. Ghafoor A, Gill MA, Hassan A, Murtaza G \& Qadir M (2001). Gypsum: An economical amendment for amelioration of saline-sodic waters and soils and for improving crop yield. Int J Agri Biol 3: 266-275.

35. Gupta S, Chattopadhyay MK, Chatterjee P, Ghosh B \& Gupta DNS (1998). Expression of abscisic acid-responsive element binding protein in salt tolerant indica rice (Oryza sativa L. cv. Pokkali). Plant Mol Biol 137: 629-637.

36. Halperin SJ, Kochian LV \& Lynch JP (1997). Salinity stress inhibits calcium loading into the xylem of excised barley (Hordeum vulgare) roots. New Phytol 135: 419-427.

37. Hamza MA, Anderson SH \& Aylmore LAG (2006). Computed tomographic evaluation of osmotica on shrinkage and recovery of lupin (Lupinus angustifolius L.) and radish (Raphanus sativus L.) roots. Environ Exp Bot 59: 334-339.

38. Hilda P, Graciela R, Sergio A, Otto M, Ingrid R, Hugo PC, Edith T, Estela MD \& Guillermina A. (2003). Salt tolerant tomato plants show increased levels of jasmonic acid. J Plant Growth Regul 41: 149-158.

39. Hoagland DR \& Arnon DI (1950). The water culture method for growing plant without soil. California Agri Exp Station dr. No. 347: 39.

40. Hodson MJ, White PJ, Mead A \& Broadley MR (2005). Phylogenetic variation in the silicon composition of plants. Ann Bot 96: 1027-1046.

41. Hollington PA (2000). Technological breakthroughs in screening/breeding wheat varieties for salt tolerance. In: Gupta SK, Sharma SK, Tyagi NK, eds. Proceedings of the national conference 'Salinity management in agriculture', December 1998. Karnal India: Central Soil Salinity Res Inst 273-289. 